\title{
Reproductive activity of mature Iraqi bull buffaloes Epididymis sperm quality and histological picture.
}

\author{
Ibrrhem N.S.; Al- Sahaf, M.M.H. and Alwan A.F. \\ Department of Surgery and Obstetrics, College of Veterinary Medicine, Baghdad University. Iraq.
}

\begin{abstract}
Summary: The present studywas carried out to investigate the reproductive activity of mature Iraqi bull buffaloes and effect of months changes on the epididymis sperm quality and histological picture.Two hundred and fifty (250) testes of mature buffaloes bull were collectedfrom the slaughter house from December 2010 to September 2011/three visits a week.Semen was collected from the left testes before slaughtering via aspiration fromtail of epididymis to evaluation sperm,individual motility, viability, concentration and abnormalities.After slaughtering carefully the epididymis were dissected from right testes. Dimentions and weight of the epididymis were measured.Diameters of ductuli lumen in tail of epididymis and thickness were,also measured.The present study demonstrated a significant increased $(P<0.05)$ a significant increased in length,weight, diameter and weight of the tail of epididymis in April and May, and sperm individual motility was higher $(P<0.05)$ significant in December, January and April,and the live sperm and concentrations were higher $(P<0.05)$ significantly in April,March and May,thesperms abnormalities were higher $(P<0.05)$ significant in August,July and September,the types of abnormalities demonstrated higher significance incoild tail in August and September,curled tail in August and July,detached head in July and March,proximal cytoplasmic droplet in December and July,distal cytoplasmic dropletin February and July,fracture neck in September and January. The diameter of epididymis tail ductuli lumen demonstrated higher significance in April,March and May, thickness of epididymis ductuli lumen demonstrated higher significance in April, May and March.Conclusions reproductive activity of bullbuffalo and semen physical characteristics decreased in hot months and increased in the moderate and cold months. The increase of ambient temperature in hot months lead to disturbance in reproductive activity but didn't stop it .
\end{abstract}

Key words: Male buffaloes, Epididymis, ductuli lumen, spermevalution, sperm abnormalities

\section{Introduction}

Domestic water buffaloes are common in southern Iraq, .The reproductive physiology is a limit to a full buffalo productivity, as fertility is considerably lower in this species than in cattle (Drost , 2007). Seasonal reproductive pattern is also found, and the inference from a series of studies is that seasonality is influenced by photoperiod, mediated by melatonin secretion (Zicarelli ,1997). Buffalo is a short-day breeder, becoming sexually active in response to decreasing day length in the late summer to early autumn (Arrighi et al ., 2010 ) .Buffalo bulls are capable of breeding throughout the year, but some seasonal fluctuation in reproductive function is evident in most countries where this species is reared (Sengupta et al ., 1963 ), with semen quality being poorer during summer than in winter (Yasuo et al ., 2006). On the average a buffalo bull produces 2.74 billion sperm daily and that the daily sperm production per gram of testicular parenchyma is about 13.74 million which is much less than the value of 32 million reported by Verma et al (1965). Sharma and Gupta (1979) reported 36.2 billions for the total epididymal sperm reserves per bull.In adult bulls, the relative distribution of sperm in the three major segments of the epididymis is about $30.4-33.3 \%$ in the caput, $8.79-20.5 \%$ in the corpus and $49.1-55.5 \%$ in the cauda.Moreover, the sperm numbers per gram of testicular parenchyma are much higher $(\mathrm{P}<0.01)$ at $3.5-4$ years $(85.8$ million) and $4.5-5$ years $(75.7$ million) than at $2.5-3$ years $(50.7$ million) (Sharma and Gupta ,1979).

.The present study was carried out to investigate the reproductive activity of mature Iraqi bull buffaloes and effect of months changes on the epididymis sperm quality and histological picture.

\section{Materials and Methods}

Two hundred fifty testes of mature buffalo bulls were obtained from the slaughter house from December 2010 to September 2011, 3 visit/ week, Semen samples were taken from the testes before slaughtering by injecting $1 \mathrm{ml}$ of normal saline in the tail of left testes epididymis, aspiration and semen evaluation immediately were made, or after slaughtering by the separating caudaepididymal from the left testis and they were washed by using physiological liquid $(0.9 \% \mathrm{NaCl})$. Spermatozoa were collected by using a combination of Slicing, Rinsing and Pressing Technique (rinse-press) in the $\mathrm{NaCl}$ physiological liquid to each tissue of tail epididymal (Rizal, 2005) and make semen evaluation immediately. After slaughtering the right testes were collected and placed in a plastic box which contained ice until transporting to the laboratory, the tissue which 
surrounds the testes and the epididymis were separated carefully from the testes.. The length of epididymis and diameter of caudaepidydymal were measured by (vernea) while the weight and the cauda of epididymis were weighted using digital balance.

The cauda of the left epididymis was embedded in $5 \mathrm{ml}$ of normal saline at $37{ }^{\circ} \mathrm{C}$ in a smaller petry dish , and then the tail was cut into at least 200 sections by microsurgical scissor,to perform the following microscopical examination on sperm evaluation .Sperm motility was assessed according to the method reported by Bearden and Faquay (1992), while the percentage of individual motility Ijam et al., (1990). The method of Siegmund (1979) was used to evaluate the abnormal sperm morphology.Following method of Chemineau et al.(1991) assessment of live and dead sperms was carried out. Sperm count was done according to Jindal and Panda (1980) and Sakamoto and Hashimoto (1986).

Histological sections were prepared according to Luna (1968) .Quantitative histometry of epididymis was studied on sections taken from the cauda. The diameters of the ductal lumen were measured, and the thickness was measured from the basement to the apical membrane in cross-sections of 5 tubules.Data were analyzed statistically by a complete randomized design in one -way ANOVA. Group differences were determined using Duncan Test at $(\mathrm{P} \leq 0.05)$ (Duncan, 1955; Steel and Torrie, 1980). In the statistical analyzed, (SPSS, 2008 ) was used .Group differences were determined using the least significant difference (LSD) test at $\mathrm{P}<0.05$ (Steel and Torrie, 1980).

\section{Results and Discussion}

The results obtained from the epididymal measurement showed months related differences, the results of weight are demonstrated in table (1). The table shows that epidididymal weight increased $(\mathrm{p}<0.05)$ significantly in April, May and March, then decreased in August and July. The epididymal length increased in December, April and May then decreased in August and July, respectively .The tail diameter of epididymis increased $(\mathrm{p}<0.05)$ significantly in April, May and March while decreased in August and July, respectively table (2) .While the weight of epididymis tail showed a significant increase $(\mathrm{P}<0.05)$ in April, May and December and decreased in August, July and February(table 1 ). The increases in weight, length diameter and weight of epididymis tail in these months indicated an increase of the physiological activity of the testes in these months and an increase in activity of seminiferous tubules and sperm production in the testes(Al- Sahaf and Ibrahim, 2012 ), this process is regulated by increasing testosterone hormone in moderate and cold months (Tekepetey and Amman, 1989) that resemble the morphometric measures of testes in the different seasons that increased in mating seasons and decreased in non mating seasons (Arrighi et al., 2010), and in bull (Al-Neamy,1995).These increase led to increase spermatogenesis process in these months (moderate and cold ) then decreased in hot months. An increase in testosterone, FSH and LH hormones caused an increase in diameter of testicular, seminiferous tubule diameter( Al- Sahaf and Ibrahim,2012), epithelial thickness, a decreased in interatubular spaces and an increase in testicular size, (O'shaughnessyand Sheffield 1999).This increase in the morphometric measures of epididymis in moderate and cold months as compared with hot months is a result of an increase in length and diameter of the seminiferous tubules (Attal and Courot 1963 ,), the moderate temperature and moderate lighting period led to decrease time of affecting the testes to high temperature then decrease the weight and volume of the testes and decreased the semen production (Hocherea de-Reviers et al., 1993).

Table (1) :shows the length, weight of the epididymis, weight and the diameter of the tail (Mean \pm .E).

\begin{tabular}{|l|l|l|l|l|}
\hline Months & $\begin{array}{l}\text { Length of epididymis } \\
(\mathrm{cm})\end{array}$ & $\begin{array}{l}\text { Weight of epididymis } \\
(\mathrm{gm})\end{array}$ & $\begin{array}{l}\text { Diameter of epididymis } \\
\text { tail }(\mathrm{cm})\end{array}$ & $\begin{array}{l}\text { Weight of pididymis } \\
\text { tail }(\mathrm{gm})\end{array}$ \\
\hline December & $16.92 \pm 0.22^{\mathrm{a}}$ & $19.69 \pm 0.46^{\mathrm{c}}$ & $1.74 \pm 0.07^{\mathrm{c}}$ & $6.52 \pm 0.21^{\mathrm{b}}$ \\
\hline January & $14.90 \pm 0.10^{\mathrm{d}}$ & $18.72 \pm 0.43^{\mathrm{c}}$ & $1.57 \pm 0.05^{\mathrm{d}}$ & $5.64 \pm 0.13^{\mathrm{c}}$ \\
\hline February & $14.72 \pm 0.11^{\mathrm{d}}$ & $18.36 \pm 0.48^{\mathrm{c}}$ & $1.67 \pm 0.06^{\mathrm{d}}$ & $5.43 \pm 0.12^{\mathrm{c}}$ \\
\hline March & $15.14 \pm 0.08^{\mathrm{d}}$ & $19.36 \pm 0.44^{\mathrm{c}}$ & $1.84 \pm 0.04^{\mathrm{b}}$ & $6.08 \pm 0.11^{\mathrm{b}}$ \\
\hline April & $16.46 \pm 0.12^{\mathrm{b}}$ & $21.68 \pm 0.43^{\mathrm{a}}$ & $1.88 \pm 0.05^{\mathrm{a}}$ & $7.55 \pm 0.16^{\mathrm{a}}$ \\
\hline May & $15.88 \pm 0.12^{\mathrm{c}}$ & $20.40 \pm 0.32^{\mathrm{b}}$ & $1.73 \pm 0.04^{\mathrm{c}}$ & $5.32 \pm 0.14^{\mathrm{a}}$ \\
\hline June & $14.87 \pm 0.10^{\mathrm{d}}$ & $17.04 \pm 0.34^{\mathrm{d}}$ & $1.60 \pm 0.04^{\mathrm{d}}$ & $4.58 \pm 0.09^{\mathrm{d}}$ \\
\hline July & $14.65 \pm 0.09^{\mathrm{ef}}$ & $16.40 \pm 0.31^{\mathrm{e}}$ & $1.54 \pm 0.06^{\mathrm{d}}$ & $4.53 \pm 0.10^{\mathrm{d}}$ \\
\hline August & $14.46 \pm 0.11^{\mathrm{f}}$ & $15.52 \pm 0.28^{\mathrm{e}}$ & $1.65 \pm 0.05^{\mathrm{d}}$ & $5.86 \pm 0.19^{\mathrm{b}}$ \\
\hline September & $15.03 \pm 0.07^{\mathrm{d}}$ & $17.44 \pm 0.43^{\mathrm{d}}$ & $\mathrm{P}$ \\
\hline
\end{tabular}

Small different letters that indicated a significant difference between months $(\mathrm{P}<0.05)$.

The results obtained from the sperm which were aspirated from the tail of epididymis showed months-related differences ,even if accompanied by remarkable variations between individuals, the mean individual motility increased, the results of individual motility are demonstrated in table (2). The table shows that individual motility increased significantly $(p<0.05)$ in December ,January, April and May while decreased in July , June and August. The increase in individual motility in these months indicated an increase in the physiological activity of the testes and an increases in activity of seminiferous tubules (Al- Sahaf and Ibrahim, 2012) could be 
related to an increased in the levels of hormones especially testosterone. The semen quality seemed to be more influenced by the change in the level of nutrition associated with change in seasons(Al-Azab et al., 1983) who showed that the motility is effected by the year,season and age in buffalo bull (El-Kerabiet et al., 1996). While Koonjaenak et al( 2007) found out that the sperm motility did not differ between seasons. The motility of the sperm is better in low temperature category in was obtained in spring (Al-Azab et al.,1983). The physical characteristics of the semen comparison to moderate and high temperature categories (Chandra et al., 1999).

Table (2): Characteristics of the monthly changes in buffalo semen from the tailof epididymis (Mean \pm S.E. ) :

\begin{tabular}{|l|c|c|c|c|}
\hline month & Concentration X10 /gm & $\begin{array}{c}\text { Live sperm } \\
\%\end{array}$ & $\begin{array}{c}\text { Individual } \\
\text { motility\% }\end{array}$ & $\begin{array}{c}\text { Abnormalities } \\
\%\end{array}$ \\
\hline Dec & $155.60 \pm 2.76^{\mathrm{cd}}$ & $74.56 \pm 1.18^{\mathrm{bc}}$ & $74.16 \pm 1.75^{\mathrm{a}}$ & $11.60 \pm 0.50^{\mathrm{cd}}$ \\
\hline Jan & $159.88 \pm 2.23^{\mathrm{c}}$ & $75.56 \pm 0.78^{\mathrm{b}}$ & $69.00 \pm 1.34^{\mathrm{a}}$ & $10.85 \pm 0.55^{\mathrm{cd}}$ \\
\hline Feb & $161.96 \pm 1.64^{\mathrm{c}}$ & $73.32 \pm 0.79^{\mathrm{bc}}$ & $69.72 \pm 2.75^{\mathrm{b}}$ & $11.64 \pm 0.40^{\mathrm{cd}}$ \\
\hline Mar & $170.00 \pm 1.41^{\mathrm{b}}$ & $76.40 \pm 0.93^{\mathrm{ab}}$ & $73.60 \pm 1.02^{\mathrm{a}}$ & $10.12 \pm 0.40^{\mathrm{d}}$ \\
\hline Apr & $189.12 \pm 2.18^{\mathrm{a}}$ & $79.00 \pm 0.70^{\mathrm{a}}$ & $72.92 \pm 1.18^{\mathrm{ab}}$ & $10.16 \pm 0.48^{\mathrm{d}}$ \\
\hline May & $186.92 \pm 2.68^{\mathrm{a}}$ & $76.24 \pm 0.97^{\mathrm{ab}}$ & $68.68 \pm 0.94^{\mathrm{b}}$ & $12.20 \pm 0.58^{\mathrm{c}}$ \\
\hline Jun & $166.56 \pm 2.90^{\mathrm{b}}$ & $72.92 \pm 0.92^{\mathrm{cb}}$ & $68.00 \pm 0.96^{\mathrm{b}}$ & $14.68 \pm 0.64^{\mathrm{ab}}$ \\
\hline Jul & $153.16 \pm 2.22^{\mathrm{de}}$ & $68.72 \pm 1.36^{\mathrm{d}}$ & $68.80 \pm 1.01^{\mathrm{b}}$ & \\
\hline Aug & $151.16 \pm 2.68^{\mathrm{e}}$ & $69.60 \pm 1.36^{\mathrm{d}}$ & $69.80 \pm 1.13^{\mathrm{b}}$ & $15.56 \pm 0.57^{\mathrm{a}}$ \\
\hline Sep & $160.36 \pm 2.59^{\mathrm{c}}$ & $71.36 \pm 1.06^{\mathrm{d}}$ & & $13.40 \pm 0.53^{\mathrm{bc}}$ \\
\hline
\end{tabular}

Small different letters that indicated a significant difference between months $(\mathrm{P}<0.05)$.

The concentration of sperm cells differed $(\mathrm{P}<0.05)$ significantly between months, it was high in April, May and March then declined in August ,July and December, that is demonstrated in table (2), This increase in sperm concentrations could be due to increase the physiological activity of the testes in these months and increase activity of seminiferous tubules and sperm production in the testes(Al- Sahaf and Ibrahim,2012), this process is regulated by increasing testosterone hormone, these results are correspondent to the (Zafar et al., 1988)who found that months from April to June are most suitable for semen yield.The good quality of semen buffalo and fresian bulls were bad in hot seasons and good in moderate and cold seasons (El-Kerabi et al., 1996).

Photoperiod may also have an effect on semen quality since seasonal variations in LH and testosterone secretion have been reported in bulls(Albert and Leonardo, 2004), the head breadth ,tail length and sperm length exhibited an increase during winter and spring and a decrease in summer (AL-janaby and Taha, 2001). The results of table (2), demonstrated percentage of live sperms increased significantly $(\mathrm{P}<0.05)$ in April, March and May and decreased in July , August and September .

In present work appears there was a positive significant relations between sperm motility, concentration and viability. In the months April, March and May led to increase sexual organs activity of the animals. Percent of live sperm reached to the highest level in spring and winter while decreased to the lower levels in summer.Heat stress to the testes and a decrease in sperm viability.. A variety of factors affect the viability of sperm such as variation in age ,breed ,feeding regime (Leon et al., 1991). Depending on the present results clarified in (Table 3) there was a $(\mathrm{P}<0.05)$ significant decreased in sperm abnormal morphology duringApril, March and May and $(\mathrm{P}<0.05)$ significant increased during August, July and September .

In the present study a definite seasonal influence was observed on the total number of abnormal spermatozoa in the epididymis semen, this number was found to be higher in summer and lower in spring, the high temperatures of summer adversely affected the process of spermatogenesis, resulting in a high number of abnormal spermatozoa in the months to follow like September, the correlation between semen characteristics that recorded in moderate and cold seasons corresponding with lower in abnormities in these seasons and obtained good quality of semen in these seasons as compared with hot seasons. The disturbance of semen characteristics in hot months led to decrease viability of semen (Ax et al., 1987). This results agrees with (Vogler et al., 1995) who found that the abnormality was seen in summer.That present results agreed with suggestion the increase of ambient temperature in bull led to disturbance of physical characteristics because it affected on the germ cells which are more susceptible for increasing ambient temperature and led to increased sperm abnormalities (Waites and Setchell ,1990).

The table (3) shows the types of these abnormalities percent in different months, also demonstrated the type of abnormalities in different months that showed $(\mathrm{P}<0.05)$ a significant increase coild tail in August, curled tail in August, detached head in July, proximal cytoplasmic droplet in December,distal cytoplasmic droplet in February and fracture neck in September. Buffalo age, week of collection and season influenced sperm morphology , among morphological abnormalities, only proportions of tail defects were affected by season, being higher in the rainy season and lower in summer (Koonjaenaket al., 2007). The season difference on sperm 
production was observed with the early dry season favoring sperm production best followed by late dry season (Addas, 2011).

Table (3) shows sperms abnormalities (\%) in the tail of epididymis (Mean \pm S.E )

\begin{tabular}{|l|l|l|l|l|l|l|}
\hline Month & $\begin{array}{l}\text { proximal } \\
\text { cytoplas-mic } \\
\text { droplet }\end{array}$ & $\begin{array}{l}\text { distal cytoplas- } \\
\text { micdroplet }\end{array}$ & detached head & coild tail & curled tail & Fracture neck \\
\hline Dec & $1.73 \pm 0.20^{\mathrm{a}}$ & $1.20 \pm 0.09^{\mathrm{b}}$ & $3.20 \pm 0.11^{\mathrm{bc}}$ & $3.60 \pm 0.11^{\mathrm{b}}$ & $1.10 \pm 0.03^{\mathrm{f}}$ & $0.80 \pm 0.05^{\mathrm{cd}}$ \\
\hline Jan & $1.00 \pm 0.06^{\mathrm{bc}}$ & $0.90 \pm 0.09^{\mathrm{cd}}$ & $2.00 \pm 0.17^{\mathrm{d}}$ & $2.90 \pm 0.17^{\mathrm{c}}$ & $2.80 \pm 0.12^{\mathrm{e}}$ & $1.24 \pm 0.14^{\mathrm{a}}$ \\
\hline Feb & $0.80 \pm 0.12^{\mathrm{cd}}$ & $2.04 \pm 0.04^{\mathrm{a}}$ & $1.80 \pm 0.12^{\mathrm{d}}$ & $3.10 \pm 0.23^{\mathrm{c}}$ & $2.90 \pm 0.17^{\mathrm{de}}$ & $1.00 \pm 0.02^{\mathrm{b}}$ \\
\hline Mar & $0.90 \pm 0.06^{\mathrm{bc}}$ & $0.75 \pm 0.03^{\mathrm{de}}$ & $3.40 \pm 0.23^{\mathrm{b}}$ & $2.00 \pm 0.11^{\mathrm{d}}$ & $2.70 \pm 0.03^{\mathrm{e}}$ & $0.22 \pm 0.02^{\mathrm{e}}$ \\
\hline Apr & $0.40 \pm 0.03^{\mathrm{c}}$ & $0.80 \pm 0.03^{\mathrm{de}}$ & $2.80 \pm 0.11^{\mathrm{c}}$ & $1.80 \pm 0.17^{\mathrm{d}}$ & $2.60 \pm 0.06^{\mathrm{e}}$ & $1.02 \pm 0.05^{\mathrm{b}}$ \\
\hline May & $0.70 \pm 0.04^{\mathrm{d}}$ & $1.12 \pm 0.07^{\mathrm{bc}}$ & $2.22 \pm 0.13^{\mathrm{c}}$ & $3.11 \pm 0.07^{\mathrm{c}}$ & $2.00 \pm 0.06^{\mathrm{f}}$ & $1.01 \pm 0.06^{\mathrm{b}}$ \\
\hline Jun & $0.40 \pm 0.03^{\mathrm{e}}$ & $0.90 \pm 0.06^{\mathrm{cd}}$ & $3.45 \pm 0.26^{\mathrm{b}}$ & $3.12 \pm 0.06^{\mathrm{c}}$ & $3.28 \pm 0.16^{\mathrm{c}}$ & $1.05 \pm 0.03^{\mathrm{b}}$ \\
\hline Jul & $1.52 \pm 0.05^{\mathrm{a}}$ & $1.22 \pm 0.12^{\mathrm{b}}$ & $4.03 \pm 0.02^{\mathrm{a}}$ & $3.02 \pm 0.02^{\mathrm{c}}$ & $4.07 \pm 0.05^{\mathrm{b}}$ & $0.82 \pm 0.05^{\mathrm{c}}$ \\
\hline Aug & $0.85 \pm 0.03^{\mathrm{cd}}$ & $1.95 \pm 0.12^{\mathrm{a}}$ & $3.10 \pm 0.06^{\mathrm{bc}}$ & $4.31 \pm 0.18^{\mathrm{a}}$ & $4.71 \pm 0,17^{\mathrm{a}}$ & $0.64 \pm 0.04^{\mathrm{d}}$ \\
\hline Sep & $1.12 \pm 0.07^{\mathrm{b}}$ & $0.65 \pm 1.15^{\mathrm{c}}$ & $3.35 \pm 0.20^{\mathrm{b}}$ & $3.80 \pm 0.23^{\mathrm{b}}$ & $3.17 \pm 0.09^{\mathrm{cd}}$ & $1.31 \pm 0.06^{\mathrm{a}}$ \\
\hline
\end{tabular}

Small different letters indicated a significant difference between months $(\mathrm{P}<0.05)$.

In addition, a reduction in epididymal tubular diameters at corpus level might indicate a lower functional sustainability of this organ, whose activities toward maturation and conservation of spermatozoa transiting in the lumina are well-known. The results of table (4) demonstrated that diameter of ductile lumina tail epididymis $(\mathrm{P}<0.05)$ increased significantly in April, March and May, this increase in ductile lumina tail epididymis a accompanied by an increase in thickness of tubules in the same months April, May and March .The histometric measures of epididymis showed that diameter of ductile lumina tail epididymis tubules decreased in hot months, in August, July and December, this decrease in diameter of ductile lumina tubules a companied by a decrease in thickness of seminiferous tubules in the same months in August.(Arrighi et al., 2010 andAl- Sahaf and Ibrahim. 2012). The increased in diameter of ductile lumina tail of epididymis is a result of filling the tubules with semen these demonstrated in moderate temperature and sun shine months which have high activity of the testes and good semen physical characteristics of semen table (4).

Table (4) shows the diameter and thickness of ductile lumina of the tail of epididymis( milli micron) (Mean \pm S.E. ).

\begin{tabular}{|l|c|c|}
\hline Months & Diameter of epididymis ductile lumina X10 & Thickness of ductile lumina of epididymis X40 \\
\hline December & $536.11 \pm 2.89^{\mathrm{d}}$ & $51.14 \pm 2.30^{\mathrm{b}}$ \\
\hline January & $538.32 \pm 3.46^{\mathrm{c}}$ & $48.75 \pm 1.15^{\mathrm{c}}$ \\
\hline February & $540.44 \pm 4.04^{\mathrm{c}}$ & $47.03 \pm 1.73^{\mathrm{c}}$ \\
\hline March & $559.11 \pm 3.45^{\mathrm{a}}$ & $54.12 \pm 1.15^{\mathrm{b}}$ \\
\hline April & $565.13 \pm 2.88^{\mathrm{a}}$ & $58.30 \pm 2.88^{\mathrm{a}}$ \\
\hline May & $552.17 \pm 4.04^{\mathrm{ab}}$ & $56.70 \pm 3.87^{\mathrm{a}}$ \\
\hline June & $539.35 \pm 5.20^{\mathrm{c}}$ & $51.37 \pm 1.51^{\mathrm{b}}$ \\
\hline July & $535.03 \pm 5.35^{\mathrm{d}}$ & $46.93 \pm 2.30^{\mathrm{c}}$ \\
\hline August & $534.70 \pm 5.19^{\mathrm{d}}$ & $44.77 \pm 1.73^{\mathrm{d}}$ \\
\hline September & $544.45 \pm 2.31^{\mathrm{c}}$ & $47.80 \pm 1.15^{\mathrm{c}}$ \\
\hline
\end{tabular}

Small different letters indicated a significant difference between months $(\mathrm{P}<0.05)$.

The epididymis showed moderate amount of sperm in their lumina and some of them were dead and formed a large spermatid giant cells figure (1), also showed an increase in thickness of interstitial tissues figure (2). And the epididymis showed thickened epithelial lining cells and vacuolation in the basal layer figure (3). the epididymis appeared moderately filled with sperm figure (4).

The volume of epididymis and the results obtained at the cauda level are apparently, they might be explained, taking into account the recognized role of the caudaepididymidis in storing the non-ejaculated spermatozoa. In fact, during the mating season the lumina might possibly enlarge under the pressure of sperm accumulation, and the epithelium increased its functional role. For the same reason, the organ may be possibly augmented in weight during the mating season.

Also, in Murrah buffalo bulls, a significant positive relationship between scrotal circumference and semen volume and concentration per ejaculate was reported (Pant et al., 2003), Present results demonstrated that the Iraqi buffaloes are not seasonal animals, because they are capable of being inseminated in around year, but the male reproductive organs effects by temperature in hot months (summer). 


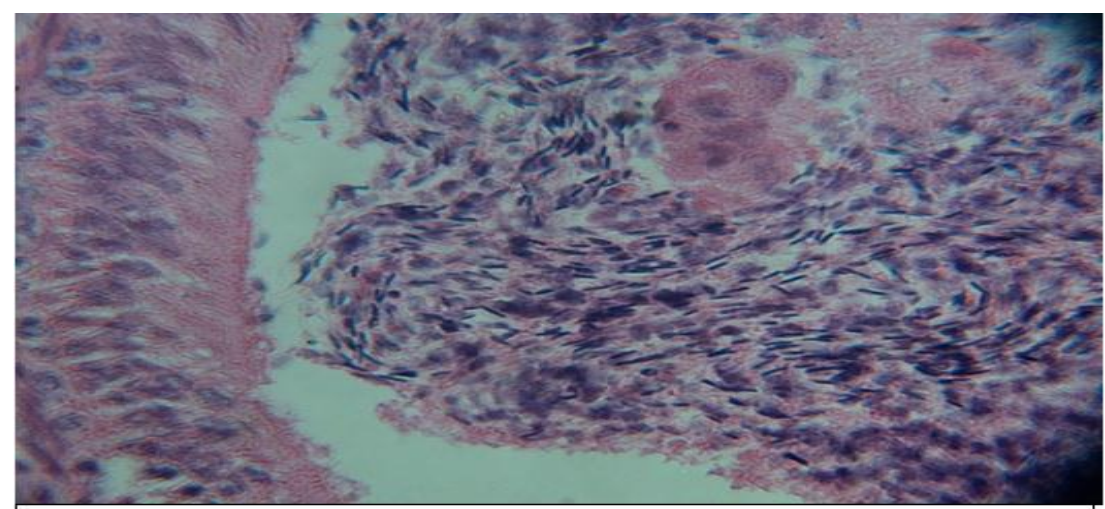

Figure (1) Epididymis of buffalo in January shows moderate number of sperms their lumina and some of them are dead to form large multinucleated giant cell ( ) (H\&E $40 \mathrm{X})$.

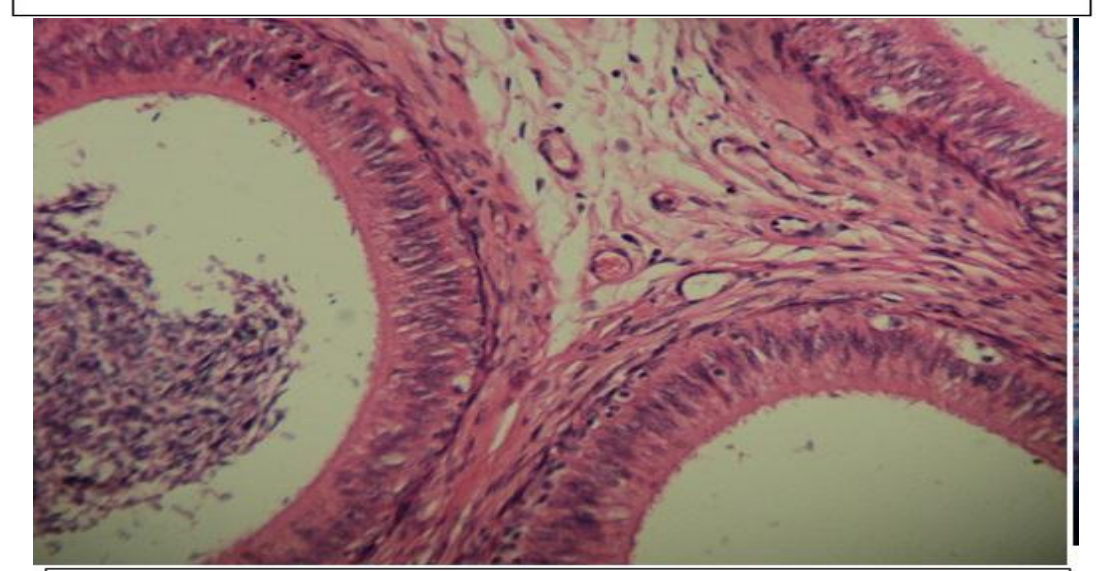

Figure (2) Epididymis of buffalo in February shows increased thickness of interstitial tissue ( ) (H\&E $40 \mathrm{X})$.

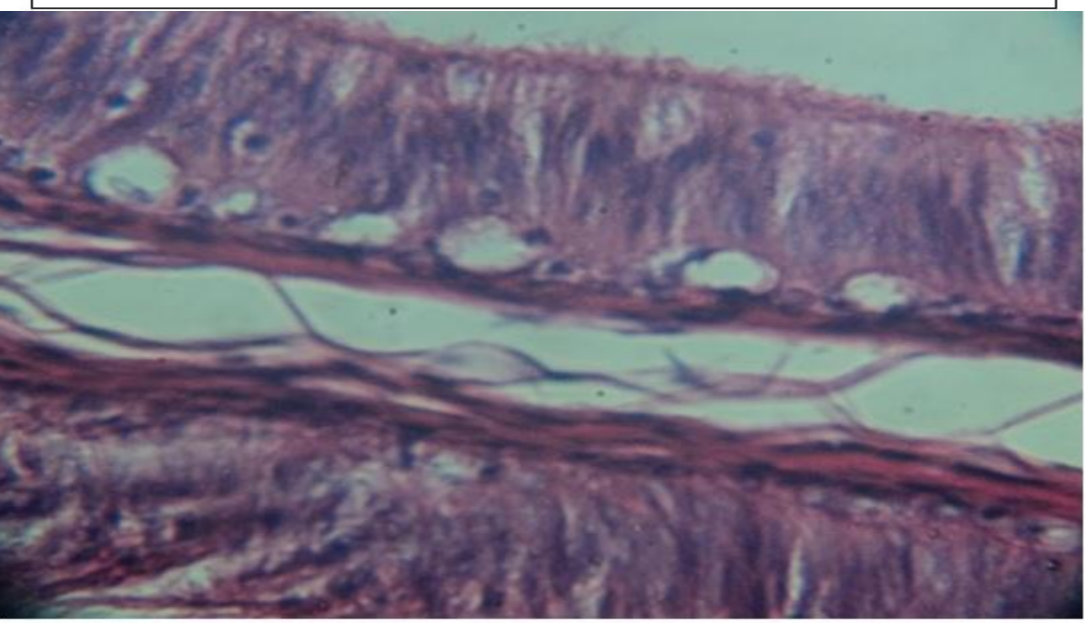

Figure (3) Epididymis of buffalo in April shows thickened epithelial lined cell with vacuolation in basal layer ( ) (H\&E $40 \mathrm{X}$ ). 


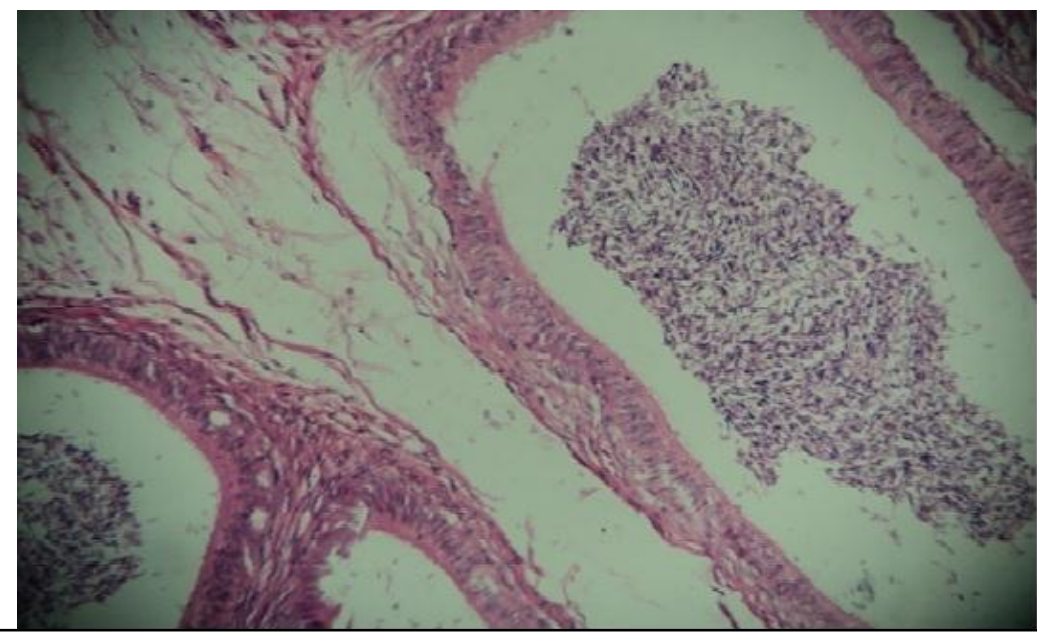

Figure (4) epididiymis of buffalo in July few sperm in lumina of epididymis (H\&E 10X).

\section{References}

[1]. Addas, P. A. (2011). Genotype and seasonal variation in testes and paired epididymalsperm production among indigenous bull cattle in Mubi Adamawa State, Nigeria.Agric. Biol. J. N. Am., 2(1): 19-22.

[2]. Al-Azab, A. I.; Rakha, A. M. and Aboul-Fadl,W.S. (1983). Interaction of season and nutrition on buffalo semen 1-physical characteristics.Egypt .J.Vet. Sci. 20, 119-127.

[3]. Albert, D. and Leonardo, F. C. (2004). Pubertal development of Bostaurus bulls .Large Ani. Vet. Rounds. Vol.4, Issue 4 .

[4]. AL-janabi, A. S. and Taha, M. N. (2001).Seasonal changes in sperm dimensions of Iraqi buffalo.Buffalo Newsletter. (15) : 265-268 .

[5]. Al-Neamy, I. M. K. (1995). Seasonal changes in reproductive system of bull in Iraq. MSc. Thesis. Vet. College University of Baghdad Pp: 22-38.

[6]. Arrighi, S. ;Bosi, G. ; Gropeptti, D. and Cremonesi, F. (2010). Morpho-and histometric evaluation on the testis and epididymis in buffalo bulls during different reproductive seasons .The Open Anatomy J.2,29-33.

[7]. Al- Sahaf, M.M.H. and Ibrahim, N.S.(2012). The effect of months on physical of sperms and morphological alterations in the testis and epididymis of Iraqi buffalo. MSc. Thesis. Vet. College University of Baghdad .Pp:48-60.

[8]. Attal, J. and Court, M. (1963). Development testicular establishment spermatogenesis .Ann.Biol.Anim.Biophys.3: 219 .

[9]. Bearden, H. J. and Faquay, J. W. (1992). Applied Animal Reproduction. $3^{\text {rd }}$ edition.Asimenznd Schuster Company, Englewood and Cliffs, New Jersey.

[10]. Ax,R .L.;Gilbert,G.R.andShook,G.E.(1987) .Sperm in poor quality semen from bulls during heat stress have a lower affinity for binding hydrogen -3 heparin .J.Diary.Sci.;70:195-200 .

[11]. Chandra, M.; Srivastava, V. K. and Shukla, A. k. (1999). Study of effect temperature on semen quantity (volume )and quality (motility )using fuzzy approach .Buffalo J.1: 105 -113.

[12]. Chemineau, p.; Cogine, Y.; Guerin, Y.; Orgeure, P. and Valtet, J. C. (1991).Training Manual on Artificial Insemination in Sheep and Goats. FAO, Animal Production Health, P.83.

[13]. Drost, M. (2007).Advanced reproductive technology in the water buffalo.Theriogenology; 68: 450-453

[14]. Duncan, D. B. (1955). Multiple range and multiple f-test. Biometrix,11: 1-24 (cited by Steel and torrie,1980).

[15]. El-Kerabi, F.; Soheir, A.; Fawzy, M.; El-Harairy, M. (1996).Comperative study of semen physical characteristic of Egyptian buffalo and fresian bulls .Bulgarian J. Agricu. Sci., 2: 5-14 .

[16]. Hochereau-de-Rievers, M. T.; Locatelli, A. Perreau, C.; Pisselet, C. and Setehell, B. P. (1993). Effect of a single brief period of moderate heating of the testes on the seminiferous tubules in hypophyctomized rams treat with pituitary extract .J.Rep.Fert.77,2: 381 .

[17]. Ijam, I.; Al-Saadi, H. and Al-Hakiem, M. (1990).Physiology of Reproduction and Artificial Insemination.MSc. Thesis College of Agriculture, Baghdad University.

[18]. Jindal, S. K. and Panda, J. N. (1980).Epididymal sperm reserves of goats (carpahircus ). J. Reprod. Fert. 59: $469-471$.

[19]. Koonjaenak, S.; Chanatinart, V.; Aiumlamai, S.; Pinyopumiminti, T. and Rodrigues, H. (2007). Seasonal variation in semen quality of swamp buffalo bulls in Thailand .Asian. J. Andro. 9: 92-101 .

[20]. Leon, H.; Porras, A. A. and Galina, C. S. (1991). Effect of the collection method on semen characteristics of Zebu and Europeon type cattle in the tropics.Theriogen., 36: 349-355.

[21]. Luna, L. G. (1968). Manual of Histology Staining.Methods of Armed Forces.Institute of Pathology. $3^{\text {rd }}$ edition.McGraw-Hill Book Company, New York and London.

[22]. O'shaughnessy, P. J. and Sheffield,J. W. (1999).Effect of testosterone on testicular steroidogenesis in the hypogonadal (hpg) mouse.J. Steroid Bioch.,35 (6): 729-734.

[23]. Pant ,H. C.; Sharma, R. K. and Patel, S. H. (2003).Testicular development and its relationship to semen production in Murrah buffalo bulls. Theriog.; (60): 27-

[24]. Rizal, M. (2005). Fertilities spermatozoa ejaculate and dombagaruthasilkriopreservasimenggunakanmodifikasipengencertrisdenganberbagaikrioprotektan and antioxidant. Disertasi,InstitutPertanian Bogor, Bogor.J.Vet.8: 188-193.

[25]. Sakamoto, J. and Hashimoto, K. (1986). Reproductive toxicity of acrylamide and related compound in mice :Effect on fertility and sperm morphology. Arch. Tixical 59: 201 -205.

[26]. Siegmund, O. H. (1979). Reproductive and urinary systems. In: The Merck Veterinary Manual. Siegmund, O. H. and Fraser, C. M. (eds). Published by Merck and Co. Inc. Rahway, N.J. USA. PP: 794-892. 
[27]. SPSS, (2008). Statistical package for the social science version 16 and 17 (win/mac/linux), users guide spssinc., Chicago 3, usn. Web site http:/ www.spss.com.

[28]. Steel, R. G. and Torrie, J. H. (1980). Principles and procedures of statistics : $2^{\text {nd }}$ ed .,MCG .raw-Hill Book ,Comp.Inc., USA.

[29]. Sengupta, B. P.; Misra, M. S. and Roy A. (1963). Climatic environment and reproductive behaviour of buffaloes. I. Effect of different seasons on various seminal attributes. Indian J. Dairy Sci. 16: 150.

[30]. Sharma, A. K. And Gupta, R. C. (1979).Estimation of daily sperm production rate by quantitative testicular histology in buffalo bulls .Ana. andEmb. Vol.3 (2): 147-152.

[31]. Tekepetery, F. R. and Amman, R. P. (1989). Localization of androgen receptors in rams epididymal principle cell. J. Reprod. Fert.87: 311-319.

[32]. Vogler, C. J.; Bame, J. H. and Dejaventte, J. M. (1995). Effect of elevated testicular temperature on morphology characteristics of ejaculated spermatozoa in bovine. Theriogenology, 40:1207-1219.

[33]. Waites, G. M. H. and Setchell, B. P. C. (1990). Physiology of the mammalian testis .In :Marshalls Physiology of Reproduction , $4^{\text {th }}$ Ed.Lamming ,G.E.Churchill Livingstone (Ed.) Edinburgh.Pp: 1-105 .

[34]. Zafar, A.H.; Ahmad, N. and Shah, S. xr1K. (1988). Effect of seasonal variation on semen production of nili -ravi buffalo bulls .buffalo J.1: 61-68 .

[35]. Zicarelli, L. (1997).Reproductive seasonality in buffalo.Bubalusbubalis; IV/97 (Suppl): $29-52$.

[36]. Yasuo, S.; Nakao, N. Ohkura, S. et al. (2006). Long-day suppressed expression of type 2 deiodinase gene in the mediobasal hypothalamus of the Saanen goat, a short-day breeder: implication for seasonal window of thyroid hormone action on reproductive neuroendocrine axis. Endocrinology ; 147: 432-440.

[37]. Verma, M. C.; Singh, G. and Sharma, M. D. (1965). Studies on sperm production. II. Testicular and epididymal sperm reserves in buffalo bulls as determined by direct counts. Indian J. Vet. Sci. Anim. Husb. 35:1-319 -331. 